\title{
Occurrence of a Novel Enzyme, L-Lysine Oxidase with Antitumor Activity in Culture Extract of Trichoderma viride
}

\author{
Hitoshi KusaKabe, Kenjiro Kodama, Haruhiko Machida, \\ Yuichiro Midorikawa, Akira Kuninaka, Haruo Misono* \\ and Kenji SODA* \\ Research Laboratory, Yamasa Shoyu Co., Ltd., Choshi 288, Japan \\ *Laboratory of Microbial Biochemistry, Institute for Chemical \\ Research, Kyoto University, Uji 611, Japan
}

Received September 18, 1978

\begin{abstract}
An aqueous extract of culture of Trichoderma viride Y244-2 on wheat bran showed antitumor activity against L5178Y mouse leukemic cells in vitro and L1210 mouse leukemia in vivo. The principle of the antitumor activity was proved to be an L-lysine-oxidizing enzyme. Oxygen consumption was accompanied by the formation of $\alpha$-keto acid, ammonia and hydrogen peroxide in the enzyme reaction with L-lysine. The ratio of amount of oxygen consumed to those of $\alpha$-keto acid and ammonia formed in the presence of catalase was approximately $1: 2: 2$. This enzyme is an L-amino acid oxidase which is highly specific for L-lysine. Thus, we designated it as L-lysine oxidase. Identity of the antitumor substance with the enzyme was confirmed by DEAE-cellulose column chromatography: the elution pattern of growthinhibitory activity against L $5178 \mathrm{Y}$ cells coincided with that of L-lysine oxidase activity.
\end{abstract}

The clinical use of $\mathrm{L}$-asparaginase ${ }^{2)}$ has stimulated the search for other enzymatic therapies for neoplastic diseases. Recently, the several enzymes that degrade essential amino acids have been shown to depress tumor growth. Phenylalanine ammonia-lyase from Rhodotorula glutinis inhibits both growth of murine and human leukemic cells in vitro ${ }^{2}$ and growth of L5178Y mouse leukemia in vivo. ${ }^{3)}$ Kreis et al. reported that methionine $\gamma$-lyase from Clostridium sporogenes causes inhibition of the growth of P815 and L1210 cells in vitro." Recently, threonine deaminase from sheep liver, which catalyzes the irreversible $\alpha, \beta$-elimination of L-threonine, was shown to inhibit the growth of mouse leukemic cells. ${ }^{5}$ No L-amino acid oxidases however, have been reported to have antitumor activity. This is probably owing to the re-amination of a-keto acids produced to yield the original amino acids through enzymatic transaminations in cells.

L-Amino acid oxidases have been isolated from various sources including microorganisms, ${ }^{(2 \sim 9)}$ snake venom, ${ }^{10}$ ) rat kidney, ${ }^{11)}$ bird liver, ${ }^{12 \sim 18)}$ and invertebrates. ${ }^{17,18)}$ L-Lysine is a poor substrate for almost all of the oxidases. The enzyme from turkey liver ${ }^{12 \sim 15)}$ catalyzes the oxidation of L-lysine, but is not specific for L-lysine: it oxidizes efficiently also other basic amino acids such as L-arginine and L-histidine.

In the course of search of new antineoplastic agents, we found a heat-labile antitumor substance with high molecular weight in the aqueous extract of culture of Trichoderma viride Y244-2 on wheat bran. The present investigation was undertaken to characterize the substance. We describe here evidence for the occurrence of a new antitumor enzyme, Llysine oxidase.

\section{MATERIALS AND METHODS}

Materials. RPMI 1640 medium $^{18)}$ was purchased from Nissui Co., Ltd. Trypsin, chymotrypsin and ribonuclease A were obtained from Sigma Chemicals $\mathrm{Co}$. Pronase was from Kaken Chemicals Co. Nuclease $P_{1}$ was prepared in Yamasa Shoyu Co., Ltd. Amino acids, vitamins and the other chemicals were of analytical grade.

Microorganism and culture. A mold, strain No. Y244-2, was isolated from a soild sample and identified as Trichoderma viride (unpublished data). The mold was grown on wheat bran at $37^{\circ} \mathrm{C}$ for 7 days. The 
cultures were extracted with 10 times amount $(\mathrm{v} / \mathrm{w})$ of water for $2 \mathrm{hr}$ at room temperature with gentle shaking. The extract is hereafter referred to as the wheat bran culture extract.

Assay of growth-inhibitory activity against L5178Y cells. L5178Y mouse leukemic cells were grown in RPMI 1640 medium containing $10 \%$ calf serum at $37^{\circ} \mathrm{C}$. The samples appropriately diluted with phosphate-buffered saline were added to 9 volumes of the suspension of cells in a logarithmic phase between $8 \times$ $10^{4} / \mathrm{ml}$ and $1.2 \times 10^{8} / \mathrm{ml}$. After incubation at $37^{\circ} \mathrm{C}$ for various periods in $5 \% \mathrm{CO}_{2}$, the number of cells was counted with a microcell-counter. Growth-inhibitory activity of the sample against L5178Y cells was shown as the minimum dilution rate required to induce $50 \%$ inhibition of the cell growth after incubation for $48 \mathrm{hr}$.

Evaluation of antitumor activity against $L 1210$ mouse leukemia. L12.10 cells $\left(1 \times 10^{5}\right.$ cells $)$ were inoculated $i . p$. in $\mathrm{BDF}_{1}$ mice on day 0 , then $0.2 \mathrm{ml}$ of the culture extract was injected $i, p$. once daily from day 1 to day 5. Increase of life-span (ILS) was calculated as follows:

$$
\text { ILS }(\%)=\left(\frac{\text { Survival time of treated mice }}{\text { Survival time of untreated mice }}-1\right) \times 100
$$

Analytical procedures. Protein concentration was measured by the method of Lowry et al. ${ }^{20}$ Ammonia was determined with Nessler's reagent by the procedure of Johnson. ${ }^{21)} \alpha$-Keto acids were determined by the method of Soda, ${ }^{223}$

Assay of oxygen consumption. Oxygen consumption was measured manometrically. The vessel contained a mixture of $20 \mu \mathrm{mol}$ of L-lysine, $170 \mu \mathrm{mol}$ of

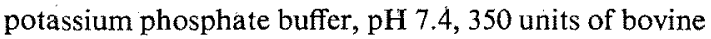
liver catalase and crude enzyme in a total volume of $2.0 \mathrm{ml}$. After the reaction mixture was incubated at $37^{\circ} \mathrm{C}$ for various times and deproteinized by addition of $0.2 \mathrm{ml}$ of $2 \mathrm{~N} \mathrm{HCl}$, ammonia and $\alpha$-keto acid were determined as described above.

Ammonium sulfate-precipitated preparation. The culture extract was brought to $70 \%$ saturation with ammonium sulfate. The precipitate collected by centrifugation was dissolved in $0.02 \mathrm{M}$ potassium phos-

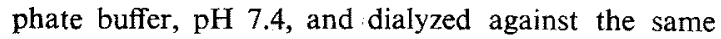
buffer. The insoluble materials formed during dialysis were removed by centrifugation.

DEAE-cellulose column chromatography. The dialyzed enzyme solution ( $3.6 \mathrm{~g}$ as protein) was applied to a DEAE-cellulose column $(4.5 \times 68 \mathrm{~cm})$ equilibrated with $0.02 \mathrm{M}$ potassium phosphate buffer, $\mathrm{pH} 7.4$. After the column was washed with 3 liters of the same buffer, the enzyme was eluted with a linear gradient of 0 to 0.6 M NaCl.

\section{RESULTS}

\section{Antitumar activity of the culture extract of} Trichoderma viride Y244-2

The wheat bran culture extract of Trichoderma viride Y244-2 was found to have an inhibitory effect on growth of L5178Y cells (Fig. 1). The complete inhibition of cell growth was shown at 1:160 dilution and 50\% inhibition was at 1:320 dilution. The sensitivity of another type of cultured cells to the

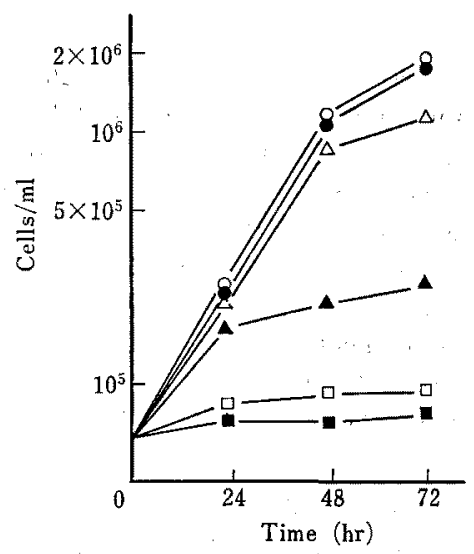

Fig. 1. Effect of the Culture Extract of Trichoderma viride Y244-2 on Growth of L5178Y Cells.

$O$, control; $\bullet, 1: 1280$ dilution; $\triangle, 1: 640$ dilution; A, $1: 320$ dilution; $\square, 1: 160$ dilution; $\square, 1: 80$ dilution.

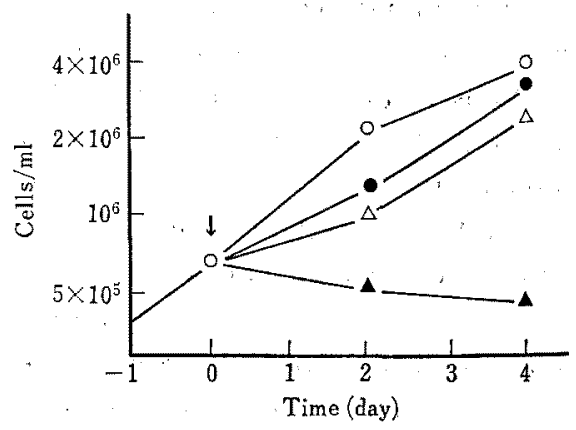

Fra. 2. Effect of the Culture Extract of Trichoderma viride Y244-2 on Growth of Mouse L-Cells.

L-Cells $\left(4 \times 10^{5}\right.$ cells/plate) were grown in minimum essential medium containing $10 \%$ calf serum. After $24 \mathrm{hr}$ incubation at $37^{\circ} \mathrm{C}$, the medium was discarded and replaced by the medium containing the culture extract at the point indicated by an arrow. The number of trypsinized cells was determined with a microcell-counter.

$O$, control; $\bullet, 1: 1280 ; \triangle, 1: 640 ; \Delta, 1: 320$. 
extract was tested. Figure 2 shows that the culture extract completely inhibited the growth of mouse L-cells at 1: 320 dilution. In addition to these in vitro activities, the extract exhibited antitumor activity in mice bearing L1210 leukemia. When administered from day 1 to 5 , the dose of $0.2 \mathrm{ml} / \mathrm{mouse} /$ day increased the life-span by $30.5 \%$.

The growth-inhibitory activity of the extract against L5178Y cells was not affected by heating at $45^{\circ} \mathrm{C}$ for $30 \mathrm{~min}$ in the $\mathrm{pH}$ range of 5 to 10 , but was lost completely by treatment at $75^{\circ} \mathrm{C}$ for $30 \mathrm{~min}$. The active fraction was fully precipitated from the extract by addition of ammonium sulfate ( $70 \%$ saturation), and was not dialyzable. This suggests that the antineoplastic substance is 'macromolecular. The activity was not influenced by the treatments with trypsin, chymotrypsin, pronase, RNase $A$ and nuclease $P_{1}$. When the ammonium sulfate-precipitated preparation was added to the culture of L5178Y cells at various growth time, the growth of the cells was immediately inhibited (Fig. 3). Cytotoxic effect of the preparation on L5178Y cells are also shown in Fig. 4. Aliquots of the cell suspension were taken out at $0,10,20$ and $40 \mathrm{~min}$ after addition of the preparation to L5178Y culture. After the cells were washed twice with RPMI

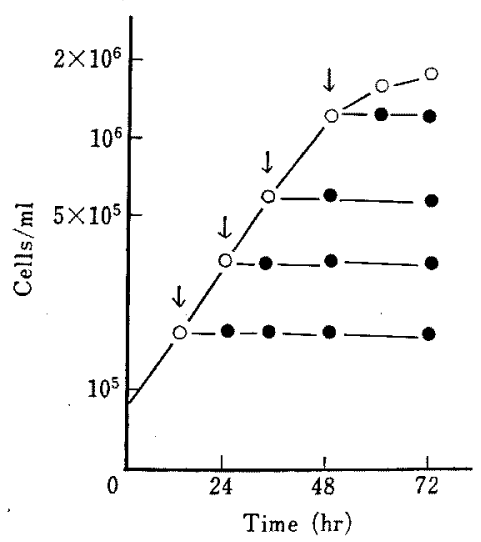

Fig. 3. Effect of Ammonium Sulfate-precipitated Preparation on Growth of L5178Y Cells.

The ammonium sulfate-precipitated preparation was added to the culture of L5178Y cells at 12, 24, 30 and $48 \mathrm{hr}$ as indicated by arrows.

0 , control;, $0.1 \mathrm{mg}$ protein $/ \mathrm{ml}$.

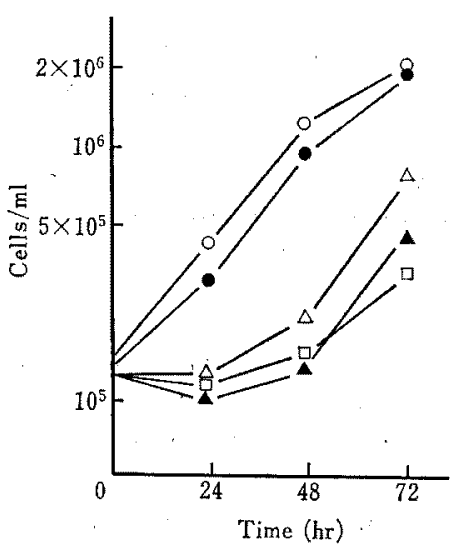

FIG. 4. Effect of Preincubation Time of L5178Y Cells with Ammonium Sulfate-precipitated Preparation on Growth of the Cells.

L5178Y cells $\left(3 \times 10^{5} / \mathrm{ml}\right)$ were incubated with ammonium sulfate-precipitated preparation $(0.1 \mathrm{mg}$ protein $/ \mathrm{ml}$ ): for various times. After the cells were washed with RPMI 1640 medium, the cells were grown in the fresh medium containing $10 \%$ calf serum. $O$, control; $\bullet, 0 \mathrm{~min} ; \triangle, 10 \mathrm{~min} ; \Delta, 20 \mathrm{~min} ; \square, 40 \mathrm{~min}$.

1640 medium to remove the active substance and resuspended in the fresh medium supplemented with $10 \%$ calf serum; the cell growth was measured over 3 days. The cell growth was depressed considerably by the treatment for 10 to $40 \mathrm{~min}$. After 2 days, the growth of these treated cells were restored.

\section{Antitumor activity and L-lysine-degrading acti- vity}

Since the antitumor substance was found to be a biopolymer as described above, we examined whether it is an enzyme that degrades a growth factor such as amino acids and vitamins required for the growth of L5178Y cells. When RPMI 1640 medium was preincubated with the ammonium sulfate-precipitated preparation at $37^{\circ} \mathrm{C}$ for $24 \mathrm{hr}$, and heated at about $75^{\circ} \mathrm{C}$ for $30 \mathrm{~min}$, the growth of L5178Y cells in the pretreated medium was significantly depressed. As shown in Table I, the growth of L5178Y cells was almost fully restored by addition of L-lysine at the same concentration as that in RPMI 1640 medium, ${ }^{19}$ ) but by none of other amino acids and vitamins contained in the medium. This finding suggests that the 
Table I. EFfects of Vitamins and Amino ACIDS ON GROWTH OF L5178Y CELLS IN THE Medium Preincubated with the Ammonium Sulfate-Precipitated Preparation

RPMI 1640 medium was preincubated with the ammonium sulfate-precipitated preparation $(0.1 \mathrm{mg}$ protein $/ \mathrm{ml}$ ) for $24 \mathrm{hr}$ at $37^{\circ} \mathrm{C}$, and then heated at $75^{\circ} \mathrm{C}$ for $30 \mathrm{~min}$. L5178Y cells $\left(2 \times 10^{8} / \mathrm{ml}\right)$ were added to each tube containing fresh or the preincubated medium supplemented by each of the medium components, and incubated at $37^{\circ} \mathrm{C}$ for $48 \mathrm{hr}$. The concentration of the components was the same as that of RPMI 1640 medium.

\begin{tabular}{|c|c|c|c|}
\hline Exp. & Medium & Addition & $\begin{array}{c}\text { Cell } \\
\text { growth } \\
(\%)\end{array}$ \\
\hline \multirow[t]{11}{*}{1} & Fresh & 一 & 100.0 \\
\hline & Preincubated & - & 30.6 \\
\hline & & Riboflavine & 33.8 \\
\hline & & Biotin & 31.7 \\
\hline & & Pantothenic acid & 32.5 \\
\hline & & Thiamine & 30.4 \\
\hline & & Nicotinamide & 31.2 \\
\hline & & Inositol & 33.2 \\
\hline & & Pyridoxine & 30.9 \\
\hline & & Choline & 32.5 \\
\hline & & Folic acid & 33.1 \\
\hline \multirow[t]{21}{*}{2} & Fresh & - & 100.0 \\
\hline & Preincubated & - & 41.3 \\
\hline & & L-Arginine & 26.3 \\
\hline & & L-Asparagine & 41.1 \\
\hline & & L-Asparagic acid & 40.7 \\
\hline & & L-Cystine & N. T. \\
\hline & & L-Glutamic acid & 47.4 \\
\hline & & L-Glutamine & 39.9 \\
\hline & & L-Glycine & 41.6 \\
\hline & & L-Histidine & 38.3 \\
\hline & & L-Hydroxyproline & 41.4 \\
\hline & & L-Isoleucine & 39.3 \\
\hline & & L-Leucine & 35.5 \\
\hline & & L-Lysine & 96.9 \\
\hline & & L-Methionine & 39.2 \\
\hline & & L-Phenylalanine & 39.2 \\
\hline & & L-Proline & 46.2 \\
\hline & & L-Serine & 44.1 \\
\hline & & L-Threonine & 40.0 \\
\hline & & L-Tryptophan & 44.1 \\
\hline & & L-Tyrosine & 44.2 \\
\hline
\end{tabular}

N. T., not tested.

antitumor substance in the culture extract is an enzyme which can degrade L-lysine, an essential amino acid for mammals, in the medium.

\section{Reaction of the crude enzyme preparation with L-lysine}

The ammonium sulfate-precipitated preparation was tested for its ability to catalyze the oxidation of L-lysine. The rate of oxygen consumption was measured manometrically. The uptake of oxygen proceeded linearly with time as shown in Fig. 5-a. Ammonia and $a$ keto acid also were formed linearly (Figs. 5-b and 5-c). Heat-treatment of the enzyme completely abolished both oxygen consumption and formation of ammonia and $\alpha$-keto acid. The ratio of amount of oxygen consumed to those of ammonia and $\alpha$-keto acid formed in the presence of catalase was approximately $1: 2: 2$. To determine whether hydrogen peroxide is produced in the reaction, oxygen consumption was measured in the presence or

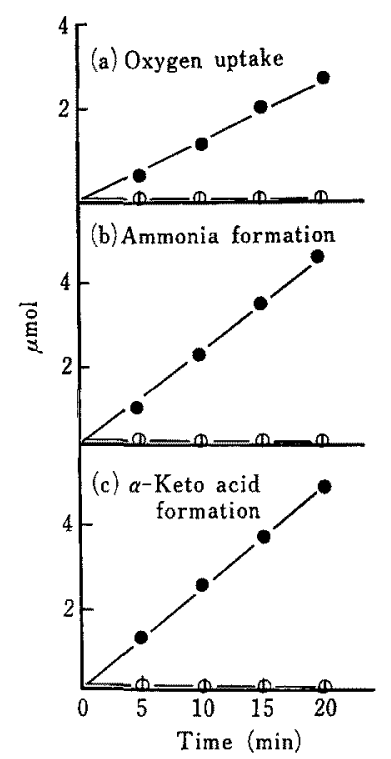

FIG. 5. Oxygen Consumption, and Formation of $\alpha$ Keto Acid and Ammonia during the Reaction of the Enzyme with L-Lysine.

Oxygen consumption was measured manometrically. The vessels contained $20 \mu \mathrm{mol}$ of L-lysine, $170 \mu \mathrm{mol}$ of potassium phosphate buffer, $\mathrm{pH} 7.4,350$ units of catalase and $0.8 \mathrm{mg}$ of the crude enzyme protein in a total volume of $2.0 \mathrm{ml}$. After 5, 10, 15 and $20 \mathrm{~min}$ of incubation at $37^{\circ} \mathrm{C}$, the reaction mixture was deproteinized with the addition of $0.2 \mathrm{ml}$ of $2 \mathrm{~N} \mathrm{HCl}$. Ammonia and $\alpha$-keto acid were determined as described in Materials and MetHods.

๑, native enzyme; $O$, heat-treated enzyme. 
TABle II. EFFect of Catalase on OXYGEN UPTAKE

Oxygen uptake was measured manometrically. The vessels contained $170 \mu \mathrm{mol}$ of potassium phosphate buffer, pH 7.4, 0 or 350 units of catalase, $20 \mu$ mol of L-lysine, and $0.2 \mathrm{ml}$ of culture extract or ammonium sulfate-precipitated preparation $(1.7 \mathrm{mg}$ as protein) in a total volume of $2.0 \mathrm{ml}$. The reaction was carried out at $37^{\circ} \mathrm{C}$ for $20 \mathrm{~min}$.

\begin{tabular}{lcc}
\hline Addition & \multicolumn{2}{c}{$\mathrm{O}_{2}$ Uptake $(\mu \mathrm{l})$} \\
\cline { 2 - 3 } & $\begin{array}{l}\text { Culture } \\
\text { extract }\end{array}$ & $\begin{array}{c}\text { Ammonium } \\
\text { sulfate- } \\
\text { precipitated } \\
\text { preparation }\end{array}$ \\
\hline None & 32.9 & 238.0 \\
Catalase & 17.7 & 175.8 \\
\hline
\end{tabular}

absence of catalase. Table II shows that oxygen consumption was significantly reduced by addition of catalase. In the experiment with the culture extract, where relatively small amount of oxygen was consumed, the rate of oxygen consumption was decreased about $50 \%$ by addition of catalase. This suggests that the oxidation of L-lysine is accompanied with the formation of hydrogen peroxide. When a considerably large amount of oxygen was consumed with the ammonium sulfate-precipitated preparation, the effect of catalase was decreased. This decline of catalase effect is probably due to a decrease of oxygen concentration and a low affinity of the enzyme for oxygen. These results show that the antineoplastic L-lysine-degrading enzyme is a kind of L-amino acid oxidase that catalyzes the oxidative deamination of lysine.

\section{Substrate specificity of L-lysine-degrading en- zyme}

The crude L-lysine-degrading enzyme preparation was examined for its ability to catalyze the oxidation of various amino acids (Table III). L-Lysine is the preferred substrate. L-Ornithine, L-phenylalanine, L-arginine and L-histidine were also oxidized to a lesser extent. The other L-amino acids tested and Dlysine were not substrates. This enzyme is distinct from L-amino acid oxidases so far studied in the substrate specificity. Therefore,
Table III. Substrate Specificity of L-Lysine OXIDASE

Oxygen uptake was measured manometrically. The vessels contained $170 \mu \mathrm{mol}$ of potassium phosphate buffer, pH 7.4, 350 units of catalase, $20 \mu \mathrm{mol}$ of Lamino acid and $1.6 \mathrm{mg}$ of protein (ammonium sulfateprecipitated preparation) in a total volume of $2.0 \mathrm{ml}$. The reaction was carried out at $37^{\circ} \mathrm{C}$ for $20 \mathrm{~min}$.

\begin{tabular}{lcc} 
Substrate & $\begin{array}{c}\mathrm{O}_{2} \text { Uptake } \\
(\mu 1)\end{array}$ & $\begin{array}{c}\text { Relative } \\
\text { activity } \\
(\%)\end{array}$ \\
\hline L-Lysine & 156.6 & 100.0 \\
L-Ornithine & 32.2 & 20.5 \\
L-Phenylalanine & 9.3 & 5.9 \\
L-Arginine & 6.4 & 4.3 \\
L-Histidine & 5.7 & 3.6 \\
L-Glycine & 0 & 0 \\
L-Alanine & 0 & 0 \\
L-Leucine & 0 & 0 \\
L-Isoleucine & 0 & 0 \\
L-Methionine & 0 & 0 \\
L-Serine & 0 & 0 \\
L-Threonine & 0 & 0 \\
L-Asparagine & 0 & 0 \\
L-Asparagic acid & 0 & 0 \\
L-Glutamic acid & 0 & 0 \\
L-Proline & 0 & 0 \\
D-Lysine & 0 & 0 \\
\hline
\end{tabular}

we designated this enzyme as L-lysine oxidase.

Identity of the antitumor substance with $\mathrm{L}-$ lysine oxidase

In order to show the identity of the antitumor substance with L-lysine oxidase, elution patterns of antitumor and L-lysine oxidase activities from a DEAE-cellulose column were compared (Fig. 6). The peak of antitumor activity coincided with that of the enzyme activity. This result also shows that the antitumor actjvity is ascribed to L-lysine oxidase.

\section{DISCUSSION}

In the present study, we identified the antitumor substance found in the wheat bran culture extract of Trichoderma viride Y244-2 as L-lysine oxidase, a new L-amino acid oxidase which is highly specific for L-lysine.

In the presence of catalase, $0.5 \mathrm{~mol}$ of oxygen is consumed per mol of $\alpha$-keto acid and ammonia formed. This and other stoichiometric 


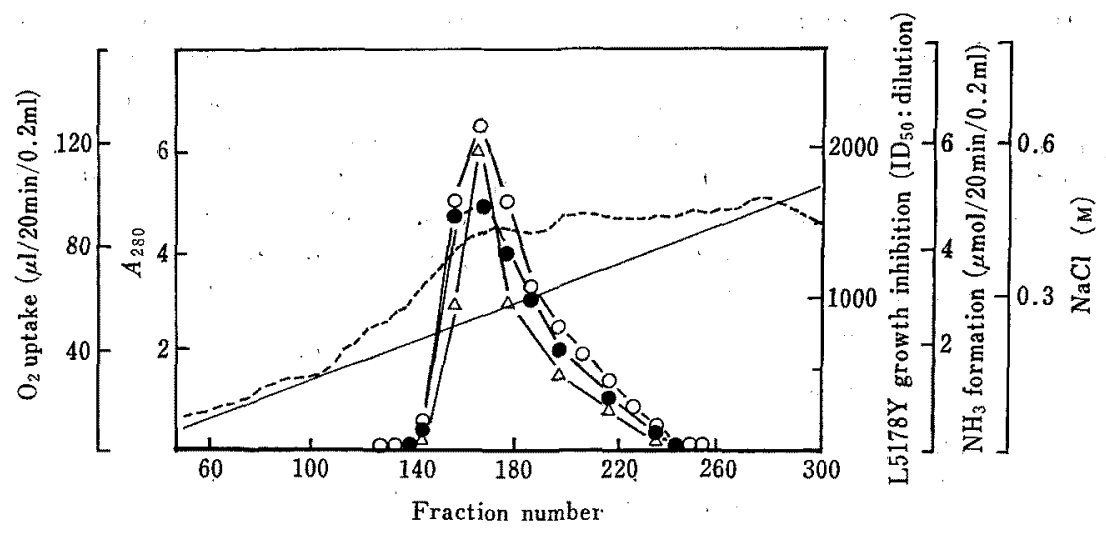

FIG. 6. DEAE-cellulose Column Chromatography of L-Lysine Oxidase.

Oxygen uptake was measured in the absence of catalase. Experimental conditions are described in Materials AND Methods. O, $\mathrm{O}_{2}$ uptake; $\bullet$ ammonia formation; $\triangle, \mathrm{L} 5178 \mathrm{Y}$ growth inhibition; -----, $A_{280} ;-, \mathrm{NaCl}$ concentration.

studies of the enzymatic oxidation of lysine (Fig 5 and Table II) show that L-lysine is oxidized to equimolar amounts of $\alpha$-keto acid, ammonia and hydrogen peroxide with consumption of equimolar amount of oxygen. We have not yet investigated which amino group of Llysine is eliminated by the oxidation. The enzyme catalyzes also the oxidation of Lornithine, L-phenylalanine, L-arginine and L-histidine. The results suggest on the analogy of the oxidation of $\alpha$-amino acids that $\alpha$-amino group of L-lysine is oxidized to yield $\alpha$-keto- $\varepsilon$ aminocaproate as follows:

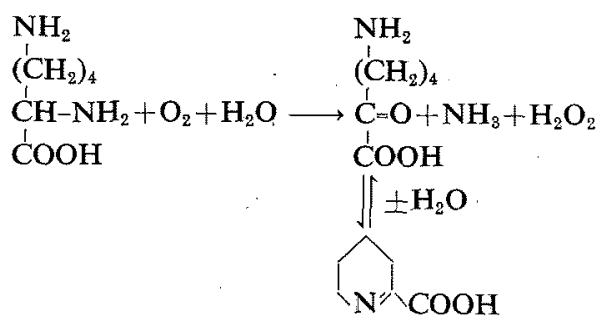

$\alpha$-keto- $\varepsilon$-aminocaproate is probably in equilibrium with the cyclized form, $\Delta^{1}$-piperideine-2carboxylate.

Most of L-amino acid oxidases from various sources act only slightly on L-lysine. The oxidases from turkey liver ${ }^{12 \sim 15)}$ and Proteus rettger $i^{9}$ oxidize effectively L-lysine and several other basic amino acids. Paik et al. reported that L-lysine can be oxidized by snake venom $\mathrm{L}$-amino acid oxidase when the $\mathrm{pH}$ is favor- able. ${ }^{23}$ However, these oxidases oxidize efficiently various other amino acids as well as L-lysine. The enzyme from Trichoderma viride Y244-2 is highly specific for L-lysine as indicated in Table III. The enzyme is unique in this regard, and thus, was designated as L-lysine oxidase. The enzyme plays probably an important role in the lysine metabolism via $\alpha$-keto- $\varepsilon$-aminocaproate ( $\Delta^{1}$-piperideine-2-carboxylate) proposed early by Rothstein. ${ }^{24 \sim 26)}$

Since the principle of antitumor activity found in guinea pig serum was identified as asparaginase, ${ }^{27,28}$ ) several enzymes that degrade a factor required for tumor growth have been studied, e.g. phenylalanine ammonialyase, ${ }^{2,39}$ tyrosine phenol-lyase, ${ }^{29}$ methionine $\gamma$-lyase, ${ }^{4}$ threonine deaminase ${ }^{5 /}$ and carboxypeptidase $\mathrm{G}_{1}{ }^{30,31}$ The antitumor activity of these enzymes except asparaginase was demonstrated with the purified enzyme preparations. In the presenct study we demonstrated a novel antitumor enzyme, L-lysine oxidase in the wheat bran culture extract of the mold. We have previously shown by the same procedure as shown in Table I that the principle of antitumor activity found in the wheat bran culture extract of Aspergillus sp. Y8-5 is a folatedeaminating enzyme. ${ }^{32}$ This procedure is, therefore, widely applicable to a screening test for the heat-labile and high-molecular 
antineoplastic substances that degrade a growth factor.

The close relationship between L-lysine oxidase activity and the growth-inhibitory activity against L5178Y cells was observed with the culture extract and the ammonium sulfateprecipitated preparation. The identity of the antitumor substance with the enzyme was also confirmed by DEAE-cellulose chromatography (Fig. 6): the fractions containing Llysine oxidase exclusively showed growthinhibitory activity against L5178Y cells. In addition, the enzyme purified to homogeneity exhibited the antitumor activity against L5178Y cells in vitro and L1210 leukemia in vivo. ${ }^{33}$, Therefore, the enzyme is responsible for the antitumor activity.

When Trichoderma viride Y244-2 was grown on a liquid medium containing potato extract at $28^{\circ} \mathrm{C}$ for 4 days, the culture filtrate diluted 1:50 showed no significant activity against L5178Y cells (data not presented). No appreciable oxygen uptake was also observed, when the culture filtrate was incubated with $\mathrm{L}$ lysine. These findings suggest that L-lysine oxidase is produced specifically by cultivation on wheat bran. The wheat bran culture is known to be suitable for the production of several extracellular hydrolases such as nuclease $P_{1}{ }^{34}$ The present work provides the first example of the production of extracellular L-amino acid oxidase by wheat bran culture. Further characterization of L-lysine oxidase and the detailed study of the enzyme production by wheat bran culture are currently in progress.

\section{REFERENCES}

1) R. H. Adamson and S. Fabro, Cancer Chemother. Rep., 52, 617 (1968).

2) C. W. Abell, W. J. Stith and D. S. Hodgins, Cancer Res., 32, 258 (1972).

3) C. W. Abell, D. S. Hodgins and W. J. Stith, ibid., 33, 2529 (1973).

4) W. Kreis and C. Hession, ibid., 33, 1866 (1973).

5) R. S. Greenfied and D. Wellner, ibid., 37, 2523
(1977).

6) P. K. Stumpf and D. E. Green, J. Biol. Chem., 153, 387 (1944).

7) S. G. Knight, J. Bacteriol., 55, 401 (1948).

8) K. Burton, Biochem. J., 50, 258 (1952).

9) J. A. Duerre and S. Chakrabarty, J. Bacteriol., 121, $656(1975)$.

10) D. Wellner, "Methods in Enzymology," Vol. XVIIB, ed. by H. Tabor and C. W. Tabor, Academic Press Inc., New York and London, 1971, p. 597.

11) M. Nakano and T. S. Danowski, ibid., p. 601.

12) P. Boulanger and R. Osteux, Compt. Rend. Acad. Sci., 241, 125 (1955).

13) P. Boulanger, J. Coursaget, J. Bertrand and R. Osteux, ibid., 244, 2255 (1957).

14) P. Boulanger, J. Bertrand and R. Osteux, Biochim. Biophys. Acta, 26, 143 (1957).

15) P. Boulanger and R. Osteux, ibid., 21, 552 (1956).

16) J. Struck and I. W. Sizer, Arch. Biochem. Biophys., 90, 22 (1960).

17) H. Blaschko and D. B. Hope, Biochem. J., 62, 335 (1956).

18) J. Roche, P. Glahn, P. Manchon and N. Thoai, Biochim. Biophys. Acta, 35, 111 (1959).

19) G. Moore, D. Mount, G. Tara and N. Schwartz, Cancer Res., 23, 1735 (1963).

20) O. H. Lowry, N. J. Rosebrough, A. L. Faar and R. J. Randall, J. Biol. Chem., 193, 265 (1951).

21) M. J. Johnson, ibid,, 137, 575 (1941).

22) K. Soda, Anal. Biochem., 25, 228 (1968).

23) W. K. Paik and S. Kim, Biochim. Biophys. Acta, 96, 66 (1965).

24) M. Rothstein and L. L. Miller, J. Biol. Chem., 211, 851 (1954).

25) M. Rothstein and L. L. Miller, J. Am. Chem. Soc., 76, 1459 (1954).

26) M. Rothstein and D. M. Greenberg, J. Biol. Chem., 235, 714 (1960).

27) J. D. Broom, Nature, 191, 1114 (1961).

28) J. D. Broom, J. Exptl. Med., 118, 99 (1963).

29) G. G. Meadows, J. DiGiovanni, L. Minor and G. W. Elmer, Cancer Res., 36, 167 (1976).

30) B. A. Chabner, P. L. Chello and J. R. Bertino, ibid., 32, 2114 (1972).

31) B. A. Chabner, D. G. Johns and J. R. Bertino, Nature, 239, 395 (1972).

32) H. Kusakabe, K. Kodama, Y. Midorikawa, H. Machida, A. Kuninaka and H. Yoshino, Agric. Biol. Chem., 38, 1753 (1974).

33) H. Kusakabe, K. Kodama, A. Kuninaka and K. Soda, in preparation.

34) M. Fujimoto, A. Kuninaka and H. Yoshino, Agric. Biol. Chem., 38, 777 (1974). 